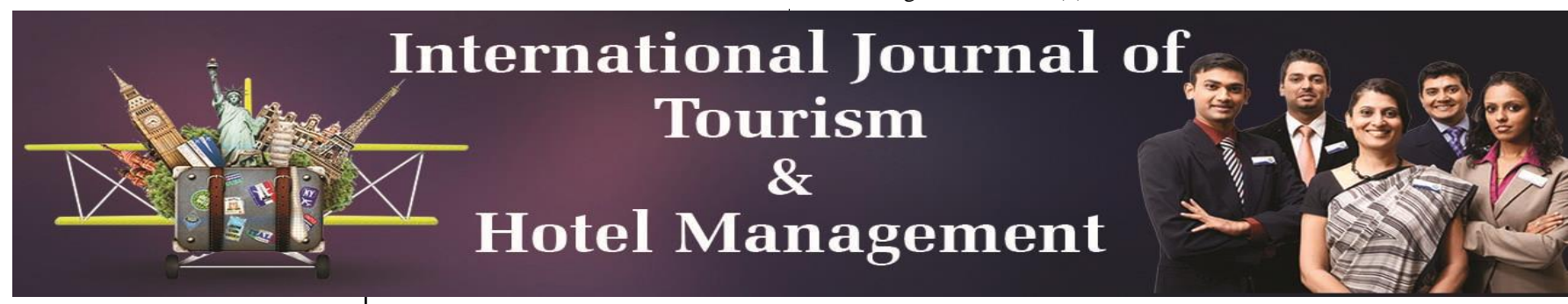

E-ISSN: 2706-9591 P-ISSN: 2706-9583 IJTHM 2022; 4(1): 01-06 Received: 01-01-2022 Accepted: 25-01-2022

Muhammad Arsalan Wani MBA (Tourism \& Hospitality Management), Baba Ghulam Shah Badshah University, Rajouri, J \& K, India

\section{Tourism in Kashmir: Development and economic impact}

\author{
Muhammad Arsalan Wani
}

DOI: https://doi.org/10.22271/27069583.2022.v4.i1a.35

\begin{abstract}
Kashmir is one of the most famous tourist destinations of India in the Himalayas. The Valley is filled with assorted rich tourism resources. For the sustainable use of these tourism resources, a proper tourism policy is requisite. Subsequently, the present study aims to examine government policy for the growth and development of tourism in Kashmir region; besides, the assessment of tourism potentials and tourist flow in Kashmir is added endeavour of the study. According to the findings, ministry of tourism government of Jammu and Kashmir has framed a draft of tourism policy so far. The draft tourism policy constitutes developmental and promotional tactics for existing and new forms of tourism, abiding the sustainable tourism approach, development of human resource and tourism infrastructure, ensuring safety and security, and encouraging tourism education within the state. Moreover, the state government is working hard to promote eco-tourism and offbeat tourist destinations in collaboration with several other concerned bodies.

Jammu and Kashmir State has a tremendous potential of becoming a major global tourist destination. Importance of tourism in $\mathrm{J} \& \mathrm{~K}$ economy is known for decades now and its role in economic development has been an area of great interest from policy perspective. To understand the economic impact of tourism in the $J \& K$ state, present paper uses secondary sources of data and tries to examine various parameters of economic development such as tourist inflow, employment generation, State Gross Domestic Product, development of infrastructure and regional development. We found apart from agriculture sector, tourism sector is the most popular source of income and employment generation for the state economy.
\end{abstract}

Keywords: tourism, tourism development, tourism policy, employment, tourist inflow

\section{Introduction}

Tourism is one of the rapidly growing sectors of the world economy. The development of the tourism sector not only increases economic growth directly, but also stimulates the growth of other sectors through backward and forward linkages and increases domestic incomes and effective demand (Gokovali \& Bahar, 2006). Tourism is an attractive tool for the economic growth, specifically in the developing world. Tourism has supported many developing countries to move away from a dependency on manufacturing and agricultural sectors. Ability of tourism to earn foreign exchange and to raise income and employment has been well recognized in economic literature (Vaugeois, 2000). Tourism industry has an extraordinary complex integration with many industries spread over many sectors and is considered as an umbrella industry containing a set of inter-related business participants (Verma, 2011). Like all other economic activities, tourism is also an economic activity and an organized industry; its dimensions are very large, its locations vary and its benefits are scattered over large segments of the population (Yadav \& Sharma, 2010). Tourism round the globe is considered as a major tool of development and in the recent past it has proved its potential by emerging as the fastest growing industry contributing about $9 \%$ to global Gross Domestic Product (GDP) and generating 8.7\% of total employment. As per the estimates of United Nations World Tourism Organisation (UNWTO), global tourism receipts hit a record by earning US $\$ 1075$ billion in 2012 (Mir, 2014).

Recently, tourism has emerged as a major industry of the Indian economy, contributing substantially to foreign exchange earnings and serving as a potential generator of employment opportunities. Amongst other Indian tourist states, Jammu and Kashmir (J\&K) is an important one and has been remained a place of attraction for tourists since centuries. The lush green forests, sweet springs, perennial rivers, pictures que, alpines scenery and pleasant climate of Kashmir valley has remained an internationally acclaimed tourist 
destination, whereas Jammu region- the land of temples is attracting a large number of pilgrim, tourists and the important destination has been Shri Mata Vaishno Devi (SMVD) (Sharma et al., 2012). Jammu and Kashmir is known as the 'Paradise on Earth'. There are about 696 tourist attractions in the three regions of the state viz, Jammu, Kashmir and Ladakh that attracts thousands of domestic and foreign tourists. Jammu and Kashmir provides various types of tourism for the tourists. Some of them are Health tourism, Adventure tourism, Ecotourism, Pilgrim tourism, Wildlife tourism etc. The picturesque beauty, large natural lakes, the snow clad mountains surrounded by thickly populated pine forests with rivers flowing through have made Jammu and Kashmir as a prime tourist attraction (Government of India, 2001). In Jammu and Kashmir, tourism has a great potential for employment generation, even for people without specialized skills. Due to its spillover effect, it provides impetus to allied sectors like Handicrafts, Handlooms and Transport. It has the capacity to provide jobs in the unorganized sector and acts as an incentive to preserve cultural and heritage assets (Government of J \& K, 2013). In the state like Jammu and Kashmir where the scope of large-scale industrialization is very limited and the potentialities of agricultural development are scarce, the role of tourism is immense in the development of the economy (Gadoo, 2011).

\section{Objectives of the Study}

The study is based on two objectives

1. To analyse the tourist inflow of J\&K state.

2. To study the economic impact of tourism in the economic development of J\&K in terms of employment, income generation, infrastructure development and regional development.

\section{Methodology}

The present study is conceptual in nature aims to investigate tourism potentials, tourist flow and tourism policy of Kashmir region. Data has been collected from various organisations like United Nations World Tourism Organisation, World Travel and Tourism Council, Ministry of Tourism Government of India, Jammu and Kashmir Tourism Development Corporation and Directorate of Tourism (Jammu/Kashmir), Economic survey of J\&K. In addition to this, data have also been collected from other reliable sources like articles, journals and newspapers.

\section{Analysis and Discussion \\ Tourism Potentials of Kashmir}

Kashmir is popularly known as "Paradise on Earth". The region is bestowed with scenic beauty, forests, lakes, singing rivers, lush green fields, meadows, snow-capped peaks, cool climate, and many socio-cultural facets. Tourism potentials of Kashmir are categorically divided into following categories:

\section{a) Natural Potentials}

Natural tourism potentials of Kashmir valley include a wide range of tourist attractions such as, Mountains, Hill stations, Valleys, Water bodies, etc. These potentials mesmerize every tourist in the valley and play a significant role in its popularity.

Table 1: Natural Tourism Potentials of Kashmir

\begin{tabular}{|c|c|}
\hline Category & Name of attraction \\
\hline Mountains & H Harmukh (5142m) Kolahoi Peak (5425m) (Amarnath Peak 5186m) Nun Kun Range, Afarwat Range etc. \\
\hline Hill Stations & Gulmarg, Pahalgam, Sonmarg, Manasbal, Dodepathri, Manasbal, Sinthan Top and Yusmarg \\
\hline Water Bodies & $\begin{array}{c}\text { Dal Lake, Wular Lake, Sheshnag Lake,Hokarsar Lake, Vishansar Lake, Tarsar Lake, Jehlem River, Sind River, and } \\
\text { Lider River. }\end{array}$ \\
\hline Valleys & Bungus Valley, Lolab Valley, GurezValley,Aru and Beetab Valley. \\
\hline Symbiotic & Dachigam National Park, Gulmarg Wild Sanctuary, Hirpora Wildlife Sanctuary and Baltal Wildlife Sanctuary, etc \\
\hline
\end{tabular}

\section{b) Cultural Potentials}

Culture of Kashmir is unique and diverse. The culture of Kashmir is one of the main tourist pull factors. The beauty of Kashmir culture lies in its attire, cuisine, language, multi faiths, different celebrations, etc. Major cultural attractions of Kashmir are enlisted in table number 2

Table 2: Cultural Potentials of Kashmir

\begin{tabular}{|c|c|}
\hline Category & Name of the Attraction \\
\hline \multirow{4}{*}{ Religious } & $\begin{array}{l}\text { Muslim: DargahHazratbal, Charar-sharief, Shrine of Pir Dastigar, Zain Shah wali, Baba Reshi, } \\
\text { Jamia Masjid Srinagar Shah Hamdans Mosque, Pather. }\end{array}$ \\
\hline & Christian: St. Marry Church, All Saints Church and Holy Family Catholic Church \\
\hline & Hindu: Amarnath Cave, Sharkia Devi, Shanker Acharia, KhirBhawani, Martand \\
\hline & Sikh: Gurdwara Chati Padshahi Srinagar, Gurdwara Parimpillan Uri, Tapayana Sahib \\
\hline Archeological and Historical & PariMahal, Hariparbat Fort, Harwan, Parihaspora, Ushkura, Semthan and Kalaroosa Caves. \\
\hline Gardens & Mugal Gardens, Tulip Graden, Botanical Garden, NasimBagh \\
\hline Handicraft & Carpets, Shawls, Embroidery, Wood carving \\
\hline $\begin{array}{l}\text { Music and } \\
\text { Dance }\end{array}$ & Ruf Dance, Bachha Nagma Dance, Ladishah, Sufiana Kalam and Chakir \\
\hline Clothing & $\begin{array}{c}\text { Pheran, Scarf /Taranga, Turban, Gown, Skullcap. Heavy/Medium woolens in winter to light } \\
\text { cottons in summer }\end{array}$ \\
\hline Cuisine & Kahwa, Namkeen Chai, Rice, Dum Aloo, and Wazwaan \\
\hline
\end{tabular}

\section{Types of Tourism in Kashmir}

There is no doubt that Kashmir is Heaven on earth. Kashmir is having immense potential from Natural to Cultural attractions. Some of the forms of tourism in Kashmir are as: 


\section{a). Religious Tourism}

Religious tourism refers to visiting to sacred places for attaining peace of mind and soul. There are a number of Muslim, Hindu, Christian and Sikh sacred places in Kashmir. Along with being spiritual and meditation centers, the pilgrim destinations of Kashmir are also a treat to the eyes. Pilgrimage tourism is gaining very much popularity in Kashmir. Every year, a number of devotees from different corners of the country visit Kashmir for religious purposes at Amarnath, Martand, Kheer Bhawani etc.

\section{b). Wildlife Tourism}

Wildlife tourism refers travel to areas to see the flora and fauna in their natural habitat. Kashmir valley is surrounded by mountains on all sides. Here, the popular wildlife attractions are Dachingam National Park, Baltal Wildlife Sanctuary and Gulmarg Biosphere Reserve. Numerous varieties of rare birds can be seen in Kashmir Valley. Nearly 187 species of breeding birds and 42 species of fishes are found in the Valley. The Black Necked Crane is a rare species of crane found in Kashmir Valley apart from Tibet and China.

\section{c). Eco-Tourism}

Eco tourism is responsible travel to the natural areas stresses conservation the environment and wellbeing of local people (Eco Tourism Society, 2015). Kashmir has mammoth potential for ecotourism which provides basic frame for ecologically sustainable tourism with livelihood opportunities for local communities State government have identified wetlands and protected as the eco-tourism sites for tourists. The major eco-tourism site in Kashmir valley are Yusmarg, Doodhpathri, Aharbal, Bungus, Lolab, Baramulla Eco Park, Gurezand andso on. The activities for tourists in these areas are: trekking, water rafting, bird watching, fishing, night camps, and forest camps.

\section{d). Cultural Tourism}

Cultural tourism can be explained as travel in order to understand the ways of lifestyle and become familiar with history of a specific location (Richards, 2003). Kashmir has a rich cultural identity across the globe. Culture of Kashmir is amalgamation of several ethnic groups of different faiths. Hospitality is one of the core aspects of its culture. People of Kashmir have deep-rooted cultural values which can be seen in the form of their dances and music, festivals, their arts and crafts and their cuisine.

\section{e). Events}

Kashmir valley is known for many traditional fair and festival events. Some of them are religious some are season based (Baisakhi, Navratri, Easter, Eid etc.) and some are promotional events. State government along with local people and other tourism stake holders celebrate these promotional fairs annually to boost cultural heritage and tourism of Kashmir.

\section{f). Adventure Tourism}

Adventure tourism refers an unusual outdoor activity and can be classified as a leisure travel activity to which the physical risk and danger is a compulsory aspect (Dar, 2014) [4]. Kashmir is one of the finest adventure destinations in the world. In fact, it is paradise of adventure lovers with high physical risks and challenges. Sky touching mountain peaks, fast flowing water bodies and open air spots of Kashmir are best for many adventure activities such as: mountaineering, trekking, rock climbing, and rafting, skiing, paragliding and so on.

\section{g). MICE Tourism}

MICE tourism is a perfect way of combining business with pleasure. MICE tourism presents unique opportunities for business development, be it an informal conversation with old partners and meetings with prospective investors, customers and suppliers, information exchange or introduction to new technologies. The Meetings, Incentives, Conferences and Exhibitions (MICE) industry is extensively and rapidly growing and is largely associated with travel for business purpose. Kashmir is acclaimed from every corner of the earth for its variety of products. Apple, Dry fruit, Handicrafts and other products of Kashmir valley attracts a huge number of business tourists across the globe annually. The Sher-i-Kashmir International Conference Centre (SKICC) and Nageen Club are two important MICE venues in Kashmir.

\section{Tourist Arrivals to Kashmir}

Tourism has emerged as an important and one of the major contributors to the state economy. Till 1989, tourism has been the major economic activity of the state. However it was hard hit following the outbreak of militancy during the past two decades. This has affected the economic stability as well as employment opportunities of its people. However tourism in the state has revived recently. Year 2016 has made history in terms of surpassing all previous records of tourists and pilgrim arrivals in the state. It is estimated that almost 13 million tourists visited J\&K in 2017 which placed J\&K on 17 th position where as Andhra Pradesh is ranked no.1 in the list of major tourist destinations of India (Ministry Of Tourism, GOI). The tourist arrivals of Jammu, Kashmir and Ladakh from 2013 to 2019 are presented in table 3

Table 3: Tourist arrivals in the state

\begin{tabular}{|c|c|c|c|c|}
\hline \multirow{2}{*}{ Year } & \multicolumn{2}{|c|}{ Kashmir Valley } & Jammu & Ladakh \\
\cline { 2 - 5 } & Amarnath & Domestic/ Foreign & Mata Vaishno Devi & Domestic/ Foreign \\
\hline 2013 & 498075 & 572100 & 6576000 & 72000 \\
\hline 2014 & 373419 & 601250 & 8235064 & 78573 \\
\hline 2015 & 458046 & 736448 & 8749000 & 76055 \\
\hline 2016 & 634000 & 1314432 & 10115232 & 179204 \\
\hline 2017 & 621000 & 1308765 & 10394000 & 178750 \\
\hline 2018 & 513969 & 1351130 & 9287871 & 217650 \\
\hline 2019 & 572909 & 1397618 & 7803193 & 216130 \\
\hline
\end{tabular}




\section{Employment Generation}

Broadly tourism generated employment may be classified in to three major heads one is direct employment that sell goods and services directly e.g. hotels, restaurants, shops etc. Second one is indirect employment, which generally supplies goods, services to the tourism business and thirdly investment related employment in construction and other capital goods industries. As per World Travel and Tourism Council (WTTC) estimates, an investment of 10 lakh in travel and tourism industry will generate about 90 jobs which are much higher than its competing sectors like Agriculture and Manufacturing which generate $45 \& 13$ jobs per10 lakh respectively. Santek Consultants Private Limited, Delhi, in her report "20 years perspective plan for the sustainable development of tourism in the State of J \& K" projected impact of tourist inflow on employment generation of J\&K from 2002 to 2020 which is presented in table 4 and figure 1.

Table 4: Generation of Employment on Implementation of Tourism Development Plan

\begin{tabular}{|c|c|c|c|c|}
\hline Year & $\begin{array}{c}\text { Additional Tourist Inflow } \\
\text { (In lakhs) }\end{array}$ & $\begin{array}{c}\text { Direct Employment } \\
\text { (in lakhs ) }\end{array}$ & $\begin{array}{c}\text { In-Direct Employment } \\
\text { (in lakhs ) }\end{array}$ & $\begin{array}{c}\text { Total } \\
\text { employment }\end{array}$ \\
\hline 2002 & 62.83 & 1.57075 & 7.85375 & 9.4245 \\
\hline 2003 & 67.43 & 1.68575 & 8.42875 & 10.1145 \\
\hline 2004 & 72.36 & 1.809 & 9.045 & 10.854 \\
\hline 2005 & 77.66 & 1.9415 & 9.7075 & 11.649 \\
\hline 2006 & 83.36 & 2.084 & 10.42 & 12.504 \\
\hline 2007 & 89.48 & 2.237 & 11.185 & 13.422 \\
\hline 2008 & 96.06 & 2.4015 & 12.0075 & 14.409 \\
\hline 2009 & 103.13 & 2.57825 & 12.89125 & 15.4695 \\
\hline 2010 & 110.73 & 2.76825 & 13.84125 & 16.6095 \\
\hline 2011 & 118.91 & 2.97275 & 14.86375 & 17.8365 \\
\hline 2012 & 127.7 & 3.1925 & 15.9625 & 19.155 \\
\hline 2013 & 137.16 & 3.429 & 17.145 & 20.574 \\
\hline 2014 & 147.34 & 3.6835 & 18.4175 & 22.101 \\
\hline 2015 & 158.29 & 3.95725 & 19.78625 & 23.7435 \\
\hline 2016 & 170.09 & 4.25225 & 21.26125 & 25.5135 \\
\hline 2017 & 182.78 & 4.5695 & 22.8475 & 27.417 \\
\hline 2018 & 196.46 & 4.9115 & 24.5575 & 29.469 \\
\hline 2019 & 211.2 & 5.28 & 26.4 & 31.68 \\
\hline 2020 & 227.08 & 5.677 & 28.385 & 34.062 \\
\hline
\end{tabular}

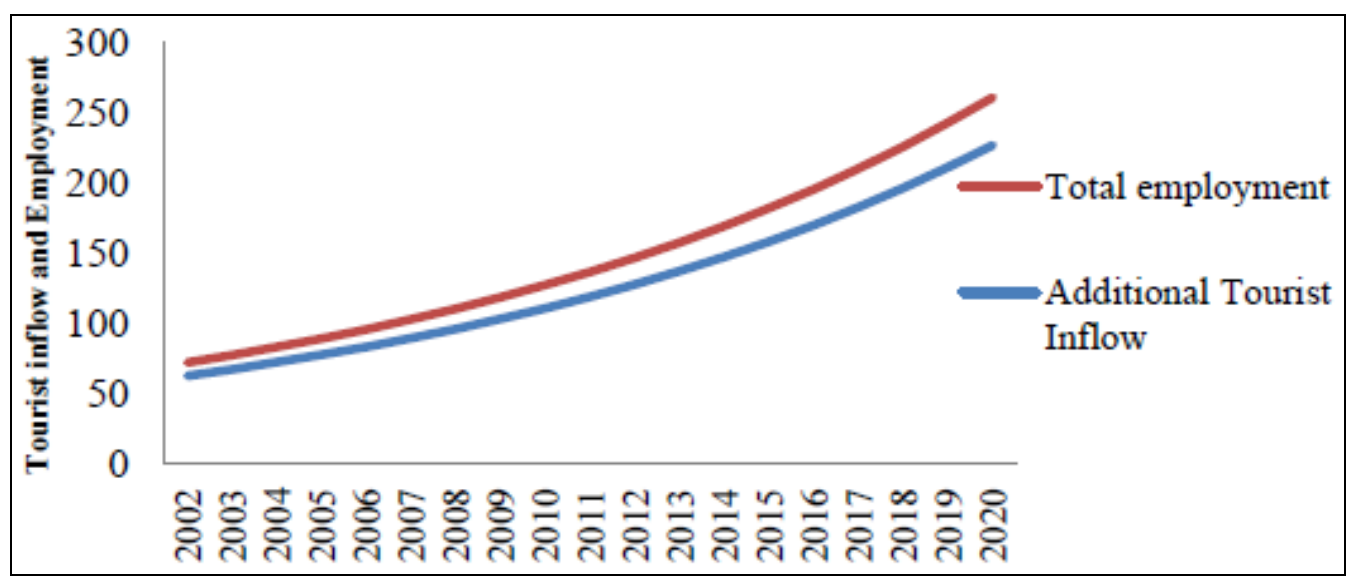

Fig 1: Impart of Tourist Inflow on Employment from 2002-2020

The upward sloping curves in the figure 1 shows that there is a positive impact of tourist inflow on employment i.e. with the increase in tourist inflow, total employment (Direct $\&$ Indirect) also rises. It means that if the current trend continues, total employment would reach to 34.06 lakhs from a tourist inflow of 227.08 lakhs till 2020. However it is important to note here that in order to meet the needs of such tourist inflow, there is a need to carry forward the developmental process in a coordinated manner.

\section{Revenue Generation}

The tourism industry in Jammu and Kashmir is one of the most flourishing industries in the state. This industry plays an important role in the development of all the regions of Jammu, Kashmir and Ladakh. As the industrial sector is not very much developed in the state so the activities related to tourism is considered with much seriousness by the state government. Apart from agriculture sector, tourism sector is the most popular source of income for the state. This sector also generates sufficient revenue for government, private sector and public sector undertaking which has shown significant increase over the years, the revenue generations is expected to increase manifold provided the conditions remains normal and the tourist influx to the state increases in a desired manner. As per the J\&K Economic Survey, during the year 2016-17, revenue realized from various sources was recorded as Rs 4362.68 lakhs showing an Increase of around $33.19 \%$ as compared to the previous year. Revenue realized in the financial year 2017-18 has touched to Rs 4692.92 lakhs. The details of revenue realized for the last 6 years are given in the table 5 . 
Table 5: Revenue generated by J\&K Tourism development Authorities (2006-12)

\begin{tabular}{|c|c|c|c|c|c|c|}
\hline \multirow{2}{*}{$\begin{array}{c}\text { Name of the department } \\
\text { / Organization }\end{array}$} & \multicolumn{5}{|c|}{ Revenue earned during last six years (in lakhs) } \\
\cline { 2 - 7 } & $\mathbf{2 0 1 2 - 1 3}$ & $\mathbf{2 0 1 3 - 1 4}$ & $\mathbf{2 0 1 4 - 1 5}$ & $\mathbf{2 0 1 5 - 1 6}$ & $\mathbf{2 0 1 6 - 1 7}$ & $\mathbf{2 0 1 7 - 1 8}$ \\
\hline Director Tourism Kashmir /Jammu & 32.25 & 62.06 & 54 & 56.65 & 72.63 & 93.3 \\
\hline SKICC & 52 & 64 & 71.2 & 65 & 110 & 114.5 \\
\hline Gulmarg Dev. Authority. & 32.46 & 48.5 & 51.17 & 34.35 & 37.32 & 145 \\
\hline Pahalgam Dev. Authority & 9.95 & 19 & 12.73 & 6.68 & 23.4 & 31 \\
\hline Sonamarg Dev. Authority & 36.35 & 32.5 & 45 & 39 & 79.4 & 10 \\
\hline Patnitop Dev. Authority & 15.62 & 79 & 20 & 19.54 & 30 & 26 \\
\hline Royal Spring Golf Course & 34.73 & 50.06 & 45.66 & 44.25 & 64.35 & 63.12 \\
\hline Cable Car Corporation & 676 & 798.81 & 839.14 & 1116 & 1248 & 1957 \\
\hline J\&K TDC. & 1765.39 & 1763 & 1963 & 1894 & 2697.58 & 2250 \\
\hline Total & 2657.75 & 2916.93 & 3101.9 & 3275.47 & 4362.68 & 4692.92 \\
\hline
\end{tabular}

The analysis of table No.5 shows that revenue generated by various authorities has increased over the years. The above table shows that except in 2014-15 when there was greater political instability in the state, the revenue earned from Director Tourism Kashmir/Jammu has shown a continuous increasing trend and has increased around three fold from 2012-13 (Rs 32.25 Lakh) to 2017-18 (Rs 93.3 lakh). Similarly income from SKICC has more than doubled over the same period. The above table further shows except in 2015-16, revenue from Gulmarg Development Authority has also shown positive trend and has increased by more than four times from 2012-13 to 2017-18. Similar trends were found from Pahalgam Development Authority from which revenue has increased from Rs 9.95 lakh in 2012-13 to Rs 31 lakh in 2017-18. The revenue from Cable Car Corporation and J\&K TDC has also increased from Rs 676 and Rs 1765 in 2012-13 to Rs 1957 and Rs 2250 in 2017-18 respectively. However the analysis of the table 3 shows that revenue from Sonamarg Development Authority, Patnitop Development Authority and Royal Spring Golf Course has shown discouraging trend. From Sonamarg Development Authority the revenue has decreased to Rs 10 lakh in 201718 after reaching at peak level Rs 79.4 lakh in 2016-17. Similarly from Patnitop Development Authority income has decreased from Rs 30 lakh in 2016-17 to Rs 26 lakh in 2017-18.

\section{Observations}

1. There are various rich natural and cultural tourism resources in Kashmir.

2. Categorically major segments of tourism are: Religious tourism, Adventure tourism, Wildlife tourism, Ecotourism and MICE tourism.

3. Tourism potentials are not fully explored in Kashmir.

4. In proposed tourism policy government has talked about the product diversification, based on the tourists profile.

5. Over the years there is fluctuation in the tourists ${ }^{\text {ee }}$ traffic to Kashmir due to insurgency.

6. There are inadequate facilities, outdated infrastructure and lack of proper tourism planning.

7. The number of foreign tourist arrivals to Kashmir is very low as compared to domestic.

8. Tourism policy of the state is not fully fledged.

9. State government work by tooth and nail on promoting Kashmir as safe, secure and friendly tourist destination.

10. Recognizing new forms of tourism and development of eco-tourism in the state are under the considerations of the government.
11. Tourism education and training is given to local people to rend quality services to tourists.

12. Film makers and other people are invited to shoot movies, dramas and other programs in Kashmir Valley.

13. In order to develop and promote Kashmir as a tourist destination, central government cooperates with J\&K government fully, directly and indirectly.

\section{Conclusion}

Kashmir region has distinctive natural and cultural tourism resources which are responsible to attract a number of tourists across the globe. There are various ups and downs in the tourist arrivals over the years due to many reasons. To maintain the tourist flow to the Kashmir, government has undertaken several initiatives, such as, expansion of tourism infrastructure, development of new tourism spots, and identification of new tourist circuits. In this regard, state tourism department has formulated a draft tourism policy. The state has also developed an eco-tourism policy for exclusive development, promotion and preservation of ecotourism potentials of the Valley. The state governments should develop strong network for the development and promotion of Kashmir tourism. In this view skilled human resource should be recruited and local people should be encourage to work in tourism business. Besides government need to do continuous review of tourism process for its smooth conduct in the region. It is evident from the above analysis that Tourism is the leading industry in the $\mathrm{J} \& \mathrm{~K}$ economy and proves to be bench strength of the state economy. Since J\&K state is one of the leading attractions for the domestic as well as international tourists, it tends to bring huge inflow of tourists who travel to seek pleasure. The Tourism sector has greater employment potential and generates sufficient revenue which has shown significant increase over the years. The revenue generation is expected to increase manifold provided the situation remains normal and the tourist influx increases in a desired manner.

\section{Suggestions}

On the basis of study findings, following are some important suggestions to tourism policy makers of Jammu and Kashmir:

1. There should be an applicable state tourism policy for the smooth conduct of tourism.

2. Creation of well trained and skilled tourism human resource is needed to serve tourists in Kashmir.

3. There should be a tourism brand ambassador for Kashmir.

4. Tourism awareness and education programs should be conducted for general people timely. 
5. Development of infrastructure at off-beat destination should be done.

6. The policy should ensure the contribution of all tourism stakeholders and a positive outcome in future.

7. Direct and indirect incentives should be given to local tourism entrepreneurs to maintain their interest in tourism field.

8. Electronic marketing should be one of the basic aims of state government for the promotion of tourism.

\section{References}

1. Mir HA. Impact of Tourism Industry on Economic Development of Jammu and Kashmir, International Journal of Scientific \& Engineering Research. 2014;5(6):592-598.

2. Mukhtar, Safeer. Sustainable tourism development with special reference to Jammu and Kashmir. International Journal of Applied Financial Management Perspectives. 2013;2(2):419.

3. Beg FB, Aima A. "Adventure Tourism Potential: a study of Kashmir" International Journal of Research in Commerce, IT and Management, 2012, 2(9).

4. Dar H. "Potentials and Problems of Adventure Tourism: A Study of Kashmir Valley." Abhinav International Monthly Refereed Journal of Research in Management and Technology, 2014, 3(9).

5. Hussain SM, Shivashanmugam. "A Study on Challenges of Tourism Industry in Jammu and Kashmir" International Journal of Scientific Engineering and Research, 2016.

6. Khan BA. "Tourism in Kashmir: Problems and Prospects." International Journal of Innovative Research \& Development, 2013, 2(4).

7. Shah F, Wani A, Mustafa Z. "Impact of Armed Conflict on Kashmir Tourism and Socio-Economic Profile of The People of J\&K" Excel International Journal of Multidisciplinary Management Studies, 2013, 3(7).

8. Kashmir G. "CM rolls out Rs 45 crores Hazratbal Development Project, 2017. Retrieved on 10/15/2017 from http://www.greaterkashmir.com/news/frontpage/cmrolls-out-rs- 45-cr-hazratbal-developmentproject/238143.html. 